\title{
Enforcement and Practicability of Sovereign Immunity Doctrine in International Commercial Arbitration
}

\author{
Rowland Alaba Akande ${ }^{1}$ \\ ${ }^{1}$ Commercial \& Industrial Law, Ebonyi State University, Abakaliki, Nigeria \\ Correspondence: Rowland Alaba Akande, Commercial \& Industrial Law, Ebonyi State University, Abakaliki, \\ Nigeria, West Africa. Tel: 234-803-774-2978. E-mail: akande@yahoo.com
}

Received: July 10, 2013 Accepted: July 17, 2013 Online Published: May 28, 2014

doi:10.5539/jpl.v7n2p143 URL: http://dx.doi.org/10.5539/jpl.v7n2p143

\begin{abstract}
Recently, in world market, States have become more involved in international business transactions. However, the various international contracts have been concluded between States and individual investors, either directly or through their State entities. The extent of the State's or State entity's commitment to arbitration clauses drafted within these commercial contracts and the fact that States seek immunity from jurisdiction and execution of arbitral award has been a major and knotty issue before arbitral award tribunals and the courts. It is on this background that, this paper will critically examine the enforcement and practicability of sovereign immunity doctrine in international commercial arbitration, and the way forward.
\end{abstract}

\section{Introduction}

The efficient and effective recognition of enforcement and execution of the arbitral award are critical to raison de etre of international arbitration. If an arbitral awards when rendered cannot be enforced against the debtor, then an essential aspect of arbitration is defeated. Therefore, a party who is successful in arbitration expects (Note 1) the award to be performed and carried out without procrastination. Hence, the essence of arbitration unlike other arbitration dispute resolution (ADR), in its decision is binding.

However, the above perception may be fatally flawed, when losing state parties do resist award enforcement and execution, the domestic law of sovereign immunity provides a near-absolute bar to attempt to enforce those awards against states. While the past decades have seen a shift in the doctrine of sovereign immunity from absolute to restrictive claims of sovereign immunity remain available to states brought before the court of another states.

In theory, an award that results from international commercial arbitration can be easily enforced in the courts of most states - the result of an international treaty regime that limits challenges to and standardized treatment of arbitral awards. This regime provides assurances to both individual investors and to states that agree to arbitration that legal recourse for resulting disputes will not be confined to that national court of either party. Nevertheless, the protection provided by the arbitration agreement is rendered illusory, if the state against which execution is sought can defend against enforcement of the award through claims of sovereign immunity. The investors having prevailed in the arbitration will be left with an award that cannot be satisfied.

The doctrine of sovereign immunity or state immunity, as it is referred to in some countries - means that a sovereign state cannot be compelled to accept the jurisdiction of another state and also, that legal action may not be brought against the state within its own borders. It is an established principle of international law which is based on the quality and independence of states. (Note 2) When this principle is applied, legal action (Note 3) can only be brought against the state where its consent has been obtained.

The erroneous application of this doctrine of sovereign immunity in the case laws particularly in the case of Liberian Eastern Timber Corporation (LETCO) v. The Government of Republic of Liberia (Note 4) and the difficulties faced by private investors in attempting to enforce arbitral award against states prompted the researcher to write on this relevant topic with a view to filling the gaps created there from.

It is against this backdrop that this paper will examine the terms; immunity from jurisdiction; nature and scope of international commercial arbitration; enforcement of international commercial arbitration in Nigeria; and then proffer necessary recommendations and conclusion. 


\section{Definition of the Terms Arbitration, International, Commercial and Awards}

\subsection{Arbitration}

All attempts to define arbitration have been fault with difficulties and the authorities are agreed that there is no universal definition of arbitration.

However, Gius Ezejiofor and Halbury's English defined arbitration as "the reference of a dispute or differences between not less than two parties for determination, after hearing both sides in a judicial manner by a person(s) other than court of competent jurisdiction. (Note 5) Redfern, A., and Hunter, M. defined arbitration as a private method of dispute resolution, chosen by the parties themselves as an effective way of putting an end to disputes between them, without result to court process. (Note 6)

The above definition show that the legal basis of every arbitration agreement is contractual found on the legal maxim pacta sunt servanda bonafide, meaning terms of an agreement shall be obeyed in good faith which makes arbitral decisions binding on the parties, and an arbitral agreement does not operate as an ouster clause. A party to arbitration can go to court any time during the arbitral process or proceedings. In Kano State of Nigeria Development Board v. Fanz Construction Company Limited, (Note 7) it was held that, an arbitration agreement does not operate as ouster clause, but, only operate as a legal right.

\subsection{International}

The lack of an internationally agreed definition of 'international' in the context of international commercial arbitration poses problems. This is because arbitration which would be considered as international in one country may not be regarded so in another country and one person definition differs from another. Nevertheless, an attempt at defining international must be made.

Grey C. Nwakoby defined international as a term used to describe those rules of law whether local, national or international which governs cross border relationship and transaction. (Note 8)

The Model Law on International Commercial Arbitration, (Note 9) and the Nigerian Arbitration and Conciliation Act, Cap. A18, Laws of the Federation of Nigeria, 2010, (Note 10) provides that arbitration would be international, if:

a. the parties to an arbitration agreement have, at the time of the conclusion of the agreement, their places of business in different country; or

b. one of the following places is situated outside the country in which the parties have their place of business -

- the place of arbitration if such place is determined in, or pursuant to the arbitration agreement,

- $\quad$ any place where a substantial part of the obligation of the commercial relationship is be performed or the place with which the subject matter of the dispute is most closely connected; or

a) the parties have expressly agreed that the subject matter of the arbitration agreement relates to more than one country; or

b) the parties, despite the nature of the contract, expressly agreed that any dispute arising from the commercial transaction shall be treated as an international arbitration.

This definition combines the two criteria mentioned earlier. The primary criteria of internationality are related to the parties, arising from their having places of business in different states, (Note 11) the dispute itself in that, for instance, the place with which the subject matter of the dispute is most closely connected may be foreign place to the parties (Note 12) and finally the choice of a foreign place of arbitration. (Note 13)

\subsection{Commercial}

Just like other terms, there is no universally accepted definition of the term "commercial" but is has now become part of the language in the field of arbitration.

Commercial means all relationships of a commercial nature including any trade transaction for the supply or exchange of goods or services, distribution agreement, commercial representation or agency, factoring, leasing, licensing, investment, construction works, consulting, engineering, financing, banking, insurance, exploitation agreement or concession, joint venture and other forms of industrial on business co-operation, carriage of goods or passengers by air, sea, rail or road. (Note 14)

Internationally, the approach is to interpret the term "commercial" as widely as possible. Although, problems have occasionally arisen because of narrow definition of commercial by courts in most countries. The general 
approach of courts of many nations is to define commercial so as to embrace all types of trade or business transaction.

\subsection{Award}

There is no definition of award in the Model Law, but, there is proposed definition which was as follows:

Award means a final award which disposes of all issues submitted to arbitral tribunal and any other decision of the arbitral tribunal which only determines any question of substance or the question of its competence or any other question of procedure but, in the latter case, only if the arbitral tribunal terms its decision an award. (Note 15)

The proposed definition shows the need to distinguish between award which are final and those which are not but fail to do it and therefore has a loophole.

It is necessary to point out here that parties to a contract must have legal capacity to enter into such contracts, otherwise, it is invalid. The position is no different, if the contract concerned happens to be an arbitration agreement. (Note 16) This is recognized in New York Convention and the Model Law; under both, enforcement of an award may be refused if the parties to the arbitration agreement were under some incapacity. (Note 17)

\section{Sovereign Immunity Defense}

State immunity exists at two levels, at the level of jurisdiction and, secondly, at the level of execution; and in considering state immunity, a distinction may need to be made between acts of a state occurring in its capacity as a state (Note 18) and those occurring in its commercial capacity. (Note 19) As a distinguishing Swiss commentator has said, this distinction is very clear in theory but very difficult to apply in practice.

The importance of the distinction (Note 20) is that, some states claim absolute immunity, which is to say immunity for all acts carried out by or on behalf of the state, while other claim restricted immunity which is to say immunity only for acts jure perii.

In other words, sovereign immunity defense has been identified to exists at jurisdiction stage and execution stage and in determining whether the sovereign immunity defense will stand at any of these stages, courts have considered the distinction between acts of state taking place in its commercial; capacity. However, as recognized by earlier European courts, it was noted that when a state enters into market place, the same treatment given to private individuals must be given to state and thereby restrict their use of sovereign immunity.

\subsection{Immunity from Jurisdiction}

Where the state itself voluntarily enters and signs an arbitration agreement, it can be implied that the state accepts the jurisdiction of an arbitral tribunal to comply with a final and binding award. The implication of this will be that the state would have been deemed to waive its immunity. In other words, such an arbitration agreement is generally held as waiver of immunity absolute restricted; (Note 21) and this emphasizes the restricted immunity theory which is reflected and adopted in some National Laws and international Conventions. That is to say that, the position has been established by legislation in some countries particularly the countries of continental Europe. (Note 22)

\subsection{Immunity from Execution}

Problems are most likely to arise when a winning party attempt to enforce and execute its ward against a state or state entity. If the state wishes to evade its obligations, it may do so by claiming immunity from execution. (Note 23)

Enforceability of an international arbitral award in national courts depends upon series of international treaties concluded between 1958 and 1965. these treaties, most prominent among them is the Convention on the Recognition and Enforcement of Foreign Arbitral Awards (Note 24) (in New York) and the Convention on the Settlement of Investment Disputes Between States and Nationals of Other States (Note 25) (in Washington), makes enforcement in all of the signatories countries arbitration awards rendered by international centre for settlement of investment disputes (ICSID) are governed by the Washington Convention, while most other international arbitrations are governed by the New York Convention.

\section{Nature and Scope of International Commercial Arbitration}

International commercial arbitration exists for the settlement of international commercial disputes between states, state entities and individual investors. It has three elements. The first is that there must be an agreement by the parties to refer dispute to an arbitration. The second is that an award must be made. The third is that the decision or award must have legal backing, that is, it may be recognized or enforced by the courts. 
The determination of the scope of the agreement involves the interpretation of the agreement and is accordingly governed by the proper law of the arbitration agreement. This will usually be the same law as that which governs the substantive contract in which an arbitral clause is embedded, but, the parties may chose different proper laws for the main contract and the arbitration agreement. This is more likely to occur in the cases of submission agreement to refer an existing dispute to arbitration.

There are in general, three categories of claims which are particularly within the scope of the arbitration agreement. These are contractual claims, claim in tort and statutory. In all the three claims, it will be pertinent to determine whether a particular claim or defense has sufficient nexus to be covered by the arbitration agreement.

Finally, any award made beyond the scope of the arbitration agreement will be set aside. This can be seen in section 48 (a) (iv) of the Arbitration Act, Cap. A18, Laws of the Federation of Nigeria.

\subsection{Advantages and Disadvantages of Institutional Arbitration}

The mayor advantage of institutional arbitration is the co-operation of a book of rules in the parties' arrangement. The provisions of the rules are handy to deal with any problems that may arise in the arbitral process, before or after the arbitral proceedings commence. For instance, a party may refuse, or fail to appoint his arbitrator to constitute a three-man arbitral tribunal, or may withdraw from the arbitral proceedings midstream. The book of rules will make provisions to deal with such situations.

The other advantage is that such institutions have a crop of well-trained staff to administer arbitration. They will ensure that the arbitral tribunal is constituted, that the arbitrators are paid there fees and expenses and generally that the arbitral proceedings are smoothly run.

The main disadvantage of institutional arbitration is that, it tends to be expensive. Where the amount in dispute is large and the administrative charges on a valorem (Note 26) basis, the amount payable is bound to be equally large. Besides, delays are bound to occur as a result of bureaucratic machinery of the institution for processing certain steps in the arbitral proceedings.

\section{Enforcement of International Commercial Arbitration in Nigeria}

Most legal writers and scholars have stated that foreign awards are enforceable in Nigeria. As a result of this, this paper will examine the provisions of the Act and cases of MSS Line v. Kano Oil Millers (Note 27), and AC Toepfer Incorporation of New York v. John Edokpolor. (Note 28)

Section 54 of the Nigeria Arbitration Act makes the Convention on the Recognition and Enforcement of Foreign Awards of 1985 (Note 29) applicable in Nigeria, and stipulate instances where the Convention will be applicable in Nigeria. The Convention is set out in the Second Schedule of the Act.

A foreign award so recognized may be registered and enforced in Nigeria pursuant to laws guiding the same, provided that the other country, if not a member of the Commonwealth, accord similar reciprocal treatment to judgments given in Nigeria - a fact which must be proved by the party seeking enforcement. (Note 30)

As stated in the earlier part of this paper, section 54 ((1) of the Nigeria Arbitration and Conciliation Act makes the Convention on the Recognition and Enforcement of Foreign Awards of 1985 applicable in Nigeria.

A foreign award may also be enforced on the basis of Foreign Judgment (Reciprocal Enforcement) Act Nos. 31 of 1960 as amended and presently referred to as the Foreign Judgment (Reciprocal Enforcement) Act, Cap. 152, Laws of the Federation of Nigeria, 1990, it may be enforced pursuant to the provisions of International Centre for Settlement of Investment Disputes (Enforcement of Awards) Act, Cap. 189, Laws of the Federation of Nigeria, 1990.

\subsection{Problems and Prospects of Enforcement of Enforcement of International Commercial Arbitral Awards in Nigeria}

The aim of this sub-heading is to take a close look on the problems and prospects of enforcement of international commercial arbitral awards in Nigeria and they are identified and subsequently discussed below.

\subsubsection{Problems}

There are some known obstacles or problems which if allowed to continue, might hinder the full realization of arbitration and enforcement of arbitral awards in Nigeria. In other words, it is now proposed to examine some of these problems.

a) Unfamiliarity with international law and general lack of information and materials on arbitration and public international law. 
b) Implications of "commercial" and "reciprocity" declarations.

c) Conflict of laws.

d) Non-implementation or defective implementation of some Conventions by municipal legislation.

e) Public policy.

f) The prevention of the defense of sovereign immunity from execution.

\subsubsection{Prospects}

It is only when one can identifies the problems of a particular thing that one can then thinks of finding solution to it. The following therefore, are some of the prospects of enforcement of international commercial arbitration award in Nigeria:

a) A specialized and autonomous mechanism for recognizing and enforcing foreign arbitral awards.

b) Dissemination of information and materials.

c) Provision of Asian-African legal consultative Committee. (Note 31)

d) Procurement of waiver of immunity from execution problems, and further weakness in enforcing foreign award particularly ICSID awards.

e) Utilization of Nigerian courts to recognize and enforce ICSID awards.

\section{Recommendations}

If international arbitration agreements are to remain useful instruments for the protection of investments, it is important that what they promise continues to be similar to what they actually deliver. In past, this requires closing the loophole that sovereign immunity currently creates in the enforcement and execution of awards and this can be done in various ways.

\subsection{Entry Judgment Clause in Arbitration Agreement}

One of the possible strategies that a private party can involve is to have an "entry of judgment" clause in the arbitral agreement. Whereby, it will be made clear that the national courts may enforce the arbitration agreement, and award resulting from it.

\subsection{Waiver}

Waiver is also commonly recommended as a solution to the dilemma of execution of immunity. These waivers could come either in a BIT or any contract that an investor concludes with the state or a subsidiary of the state. For reasons that are explained below, there are both unlikely and potentially unconstructive in the context of BIT arbitration, though, they sow soma greater promise in the contractual context.

\subsection{Changing Investor Expectations}

International arbitration insulates investors from the vicissitudes of national courts. BIT'S attempt to protect the investor's expectations and so to increase capital flow by stabilizing the legal environment of an investment. Sovereign immunity is so troubling in the arbitration context because it permits a state to have all the benefits of investment without requiring it to secure to the investor the agreed protections. States, in effect, are not required to fully internalize the costs of their policy decision. (Note 32)

\subsection{Consideration of State Membership of New York Convention}

It is also advisable for the parties to take the opportunity of considering if the state party is a contracting member of the New York Convention of 1958, which has been ratified by many states. This makes it easy for the investor to enforce an arbitral award against the assets of state party, which is in any of the other contracting member state. Article 111 of the New York Convention states that "each contracting state shall recognize arbitral awards as binding and enforce them in accordance with the rules of procedure of the territory where the award is relied upon."

\subsection{Enactment and Amendment of Sovereign Immunity Laws}

It is the humblest view and suggestion of this paper that sovereign immunity laws should be enacted in every state and existing laws on same to be amended to cover and or indicate the properties of the state for execution of arbitral awards of international arbitration whether the said properties are used for commercial purpose or not. This will remedy the defects and or difficulties faced by a private investor in attempting to enforce foreign arbitral awards. 


\subsection{Amendment of Nigerian Arbitration Act}

This paper is of the view that the Nigerian Arbitration and Conciliation Act should be amended to cover and remedy some of the defect provisions of the Act. They are as follows:

a) Section 57 (1) of the Arbitration Act should be amended to provide a comprehensive definition of the word "arbitration" because the word "commercial" as used in the definition of domestic arbitration is circuitous and unexhaustive.

b) Section 51 of the Act should be amended to provide for the enforce of foreign awards made in other countries other than Nigeria, if that other country accords substantial reciprocity of treatment to award made in Nigeria because it would seem unreasonable and unjust to do otherwise.

\section{Conclusion}

While immunity from execution is the last fortress, the last bastion of state immunity, this fortress lacks a solid formalize. The international arbitration regime attempts to encourage state activity and capital flow by providing protections for private investors, including allowing those investors to settle disputes through international arbitration proceedings instead of the sovereign courts.

Sovereign immunity is an effective legal method for a state to avoid compensating private parties for such awards, but, if the international investment regime is to continue to encourage capital flow, it cannot remain so.

This paper suggests that the doctrine, usually relegated to a sentence, at best, in the literature on international arbitration, observes much more intense scrutiny. There are significant and valid policy concerns that govern national's courts' hesitance to encroach on the sovereign of another state through execution of an arbitration award.

Ultimately, an excess of caution may undermine not only the protection of foreign investors, but, the goals of the state party to the arbitration. By restricting recovering on international arbitral awards, national courts may available through transnational investment.

This paper is focused on international commercial arbitration which has become the norm for resolving international commercial disputes for parties of different nationalities who may speak from dramatically different legal systems and cultures.

However, this paper covers Africa with particular reference to Nigeria since sovereign immunity claim remains the most significant barrier to automatic enforcement and execution of properly rendered arbitral awards in Nigeria as a giant of Africa, Liberia and other jurisdiction in the regime.

The law of sovereign immunity is formulated by each state pursuant to its own traditions; such form it is not international law. (Note 33) The most substantial assets held by most states against which a private investor secures judgment are its embassy premises, account, diplomatic and consular residences. However, during this voyage, reference has been made to Nigeria, United Kingdom, United States of America as well as others that are analysised in this paper and the case-laws.

\section{Notes}

Note 1. Adopted in San Francisco (California) USA on 26th June, 1945 and was finally ratified by the 51 original member States on 24th October, 1945 and since 1947, October, 24 has been commemorated as "United Nations Day" the General Assembly sat for the first time on January 10, 1946 in London. The value of international arbitration is grounded in expectation. Williams W. Park and Alexander A. Yanos, Treaties Obligations and National Law: Emerging Conflicts in International Arbitration, 58 HASTING L.J. 251, 2006 (asserting that the significance of arbitration as a method of disputes resolution is that it "enhance with the business community that commercial commitments will be respected.")

Note 2. See Lewis, J. Mistelis and Krollis, Comparative International Commercial Arbitration. The Hague, London, New York, Kluwer Law International, 2003, p. 744.

Note 3. This includes all forms of disputes resolution. For instance, legal suit brought before a court of competent jurisdiction as well as arbitral proceedings.

Note 4. 650 F. Supp. 73, 77 (S.D.N.Y, 1986); 854 F. 2nd 1314 2d Cir., 1987 is the locus classicus in the application of the doctrine of state immunity in international commercial arbitration and that is why the writers decided to review the case-law. 
Note 5. The Law of Arbitration in Nigeria, Longman Nigerian Plc., 1st ed. February, 1977 p. 3

Note 6. Law and Practice of International Commercial Arbitration (4th ed.) London, Sweet and Maxwell, 2004, pp. 551 to 552

Note 7. (1990) 6 SCNY p. 77

Note 8. " Recognition and Enforcement of Foreign Arbitral Award in Nigeria”, UNIZIK Law Journal, vol. 1, No. 2, February, 1999

Note 9. See Article 1 (3)

Note 10. See section 57 (2).

Note 11. Model Law, Article 1 (3) (a).

Note 12. Model Law, Article 1 (3) (b) (ii).

Note 13. Model Law, Article 1 (3) (b) (i).

Note 14. See section 57 (1) of the Nigerian Arbitration and Conciliation Act, Cap. 19, Laws of the Federation of Nigeria, 2010.

Note 15. Recourse Against the Award; Enforcement of the Award UNTIRL'S.

Note 16. See Articles 1 to 3.

Note 17. New York Convention Article v. (a); Model Law Article 36 (1) (a).

Note 18. That is, acts jure imperii.

Note 19. That is, acts jure gestionis.

Note 20. which is considered in more details below particularly immunity from execution.

Note 21. Which must be taken as extending to the jurisdiction of the relevant national court at the seat of the arbitration to supervise the arbitration taking place in its territory.

Note 22. Whilst this position has evolved from case-law in some countries.

Note 23. See footnote 6 above.

Note 24. Convention on the Recognition and Enforcement of Foreign Arbitral Awards, June 10, 195821 UST 2517, 330 UNTST (hereinafter referred to as New York Convention).

Note 25. Convention on the Settlement of Investment Disputes Between States and Nationals of other States, March 18, 1965, 17 UST 2517, 330 UNTS (hereinafter referred to as in Hinton Convention ).

Note 26. such as ICC.

Note 27. (1974) 1 ALR p. 501.

Note 28. (1965) All NLR p. 292.

Note 29. Otherwise known as the New York Convention.

Note 30. See section 54 (1) of the Arbitration and Conciliation Act, Cap. 19, Laws of the Federation of Nigeria, 1990.

Note 31. See B.S. Chimni, A Regional Centre for Arbitration, New Delhi 12 to 14 March, 1994, p. 105.

Note 32. This is because arbitrations are not centralized and are not all reported, reputation effects for state of a refusal to comply with an award may be slow to manifest.

Note 33. See United Nations Convention on Jurisdictional Immunity of States and their Property, U.N. Document A/59/49, December, 2, 2004 - represents an attempt to formulate more uniform international law on the subject.

\section{Copyrights}

Copyright for this article is retained by the author(s), with first publication rights granted to the journal.

This is an open-access article distributed under the terms and conditions of the Creative Commons Attribution license (http://creativecommons.org/licenses/by/3.0/). 